\title{
Introducing Time based Competitive Advantage in IT Sector with Simulation
}

\author{
Rida Maryam \\ Department of Computer Science \\ COMSATS Institute of Information \\ Technology, \\ Islamabad, Pakistan
}

\author{
Adnan Naseem \\ Department of Computer Science \\ COMSATS Institute of Information \\ Technology, \\ Islamabad, Pakistan
}

\author{
Junaid Haseeb \\ Department of Computer Science \\ University of Management and \\ Technology, \\ Sialkot, Pakistan
}

\author{
Khizar Hameed \\ Department of Computer Science \\ University of Management and \\ Technology, \\ Sialkot, Pakistan
}

\author{
Muhammad Tayyab \\ Department of Computer Science \\ University of Management and \\ Technology, \\ Sialkot, Pakistan \\ Babar Shahzaad \\ Department of Computer Science \\ University of Management and \\ Technology, \\ Sialkot, Pakistan
}

\begin{abstract}
Incompletion of projects in time leads to project failure which is the major dilemma of the software industry. Different strategies are used to gain a competitive advantage over competitors in business. In software perspective, time is an incredibly critical factor, software products should be delivered in time to gain competitive advantage. However, at a halt, there is no such strategy that covers time perspective. In this paper, a time-based strategy for software products is introduced. More specifically, the importance of time-based strategy by analyzing its associated factors is highlighted using simulations.
\end{abstract}

Keywords-Business strategy; competitive advantage; timebase; a competitor; simulation; software industry

\section{INTRODUCTION}

A strategy is responsible for designing plan of actions and assigning required resources to achieve long-term goals of an organization [1]. The strategy is viewed as the process of creating a unique and valuable position by means of a set of activities in a way that creates synergistic pursuit of the objectives of a firm [2]. In terms of its importance, strategy helps to gain substantial advantages and it is considered as a vital source for generating favorable situations between the firm and its competitors [3], [4]. The strategy is a pattern of resource allocation that enables firms to maintain or improve their performances [5]. Identify trends and opportunities in the future. The firm can strive to gain competitive advantage over its competitors only when it maintains a difference with competitors [3]. Entire visualization of the firm is created by business strategy. The business strategy describes the internal and external condition of firm required for competing with competitors. It is crucial that goals and missions of organization would be clear to everyone. The strategy provides help to stable firm's goal.

Since the 1980s, competitive advantage is the most significant concerns of business administration. In a business perspective, competitive advantage is described as an attribute and unique features through which an organization outperforms its competitors for the targeted market [6]. Researchers have different opinions about the concept of competitive advantage and widely studied in [3], [7]-[9] to analyze the firm's performance. Competitive advantages can take a number of perspectives; these can include organizational structure and process [10], knowledge and capital derived from employees [11], all of which constitute resources residing internally within the firm. There are three basic categories of competitive strategies [12] that can be applied by companies in order to achieve sustainable competitive advantages: low-cost leadership, Differentiation, and focus. The differentiation and cost leadership are two major strategies to compete with opponent firms [6], [13]-[15]. Finally, by forming a business strategy a firm can achieve competitive advantage competitive advantage and eventually realize more about their current and future situations.

In time-based competition, time is a critical source and most important factor for gaining competitive advantage in a worldwide context. "Time-based competition will be the rule of the day" [16]. Strategic timing is the primary choice of the firms, to become the first, second or last move to the market [17]. The purpose of the time-based strategy is to trim down the time for the completion of the task. "Time-based Competitors are offering greater varieties of products and services, at lower costs and in less time than are their more pedestrian competitors" [18]. Researchers, practitioners, and companies demonstrated through case studies, surveys and empirical approaches that the business and IT (Information Technology) performances are tightly coupled [19]-[27] and enterprises cannot be competitive if their business and IT strategies are not aligned. Time consideration in IT firms is even more curious. According to the Chaos report, only 16.2\% projects can complete on time, remaining may fail due to the delay in completion time [28]. As time is a very critical factor in the production of software, in this paper, a time-based strategy for software products is introduced. Multiple factors associated with time perspective are identified and finally, the positive and negative effects of these factors are analyzed using simulations so that importance of time-based factors can be 
highlighted. Time base simulations will provide a systematic view, when and how to launch a software product to get the maximum competitive advantage either it should be in time, pre-time or post time launch.

Remaining paper is structured as follows: Section II comprises extensive background knowledge. Section III discusses the importance of time-based competitive advantage. Simulation results are described in Section IV. Section V offers a conclusion and future work.

\section{BACKGROUND KNOWLEDGE}

Business competitive strategies were used to improve the business performance and to gain a competitive advantage for the firm. A survey of the literature was conducted comprising business strategies, author and year along with their main purpose as shown in Table 1.

The researchers proposed the different competitive strategies that can be used globally in a different context of business. There were three basic strategies introduced by Porter in 1980 i.e. Cost leadership, Differentiation and Focus. With the passage of time, some other strategies were added into and derived from basics ones. Customer oriented and marketoriented strategies were used in 2006 for building strategies to fulfill customer and market need. Market differentiation is a sub-strategy of differentiation used in 2007 for producing a unique product in term of marketing. Similarly, quality differentiation, service differentiation, innovation differentiation was used in 2007, 2014, 2015 and onward for building service wise and quality wise unique products. Then in 2016, innovation strategy was further extended as product innovation and process innovation for the introduction and implementation of innovative product and process respectively.

Contemporary studies proved that time is a critical factor but in existing studies, time-based factors are merged with other strategies as sub factors. So, there is a need of timebased strategy for gaining a competitive advantage against competitors.

\section{IMPORTANCE OF TIME-BASED COMPETITIVE ADVANTAGE}

Traditional business strategies i.e. Differentiation, Cost leadership and/or focus consider "time" as a subfactor having less influence in competitive advantage. It may or may not be a subfactor in businesses other than IT but here it is a critical one. Based on the literature, it is found that time is a critical factor so a trinity of factors that can influence performance is presented in Fig. 1. A company can gain its competitive advantage against its competitor by focusing on differentiation, time, and cost. A company can use a strategy to manage low cost to get competitive advantage, it may invest more money to make a unique product, if it is investing money to deliver a unique product by utilizing Differentiation strategy and launching it without focusing on time then there is a chance that its competitor might take the competitive advantage by launching a product in adequate time i.e. pre-time, in time or post time.

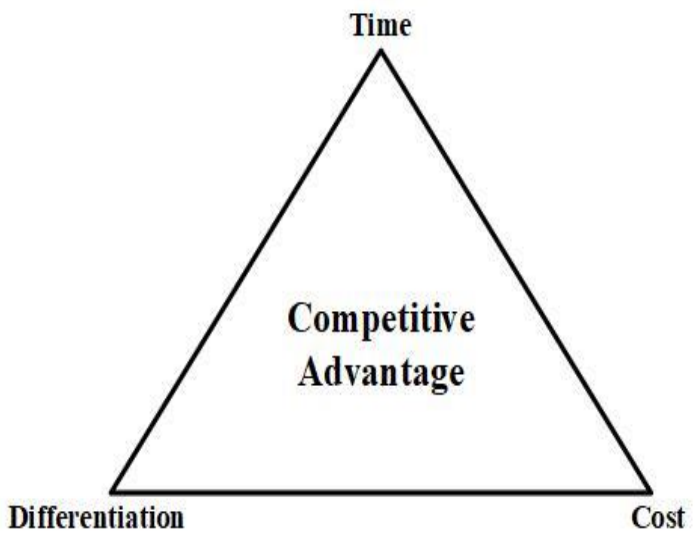

Fig. 1. Trinity of time, cost, and differentiation to gain competitive advantages.

Fig. 2 shows that individual competitive strategies have a positive impact on competitive advantage for example if a company used Differentiation as a business strategy, then it will enhance the Competitive advantage for itself. Same is the case for cost leadership (to minimize overall cost). If we talk about Time leadership or time-based strategy then it will impact on the competitive advantage positively by completing product within planned time.

The introduction to the market of the product depends upon competitor's launch. This is because both competitors are aware of each other's commercialization, launching time and features of the product by different means. The most common way is to track the events of commercialization organized by competitors to get updates about being a launching product.

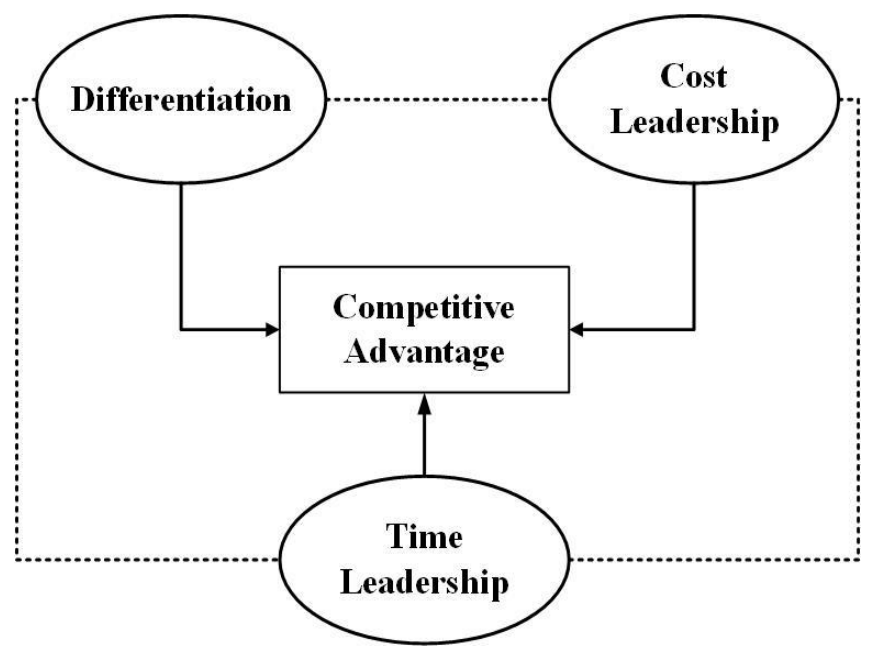

Fig. 2. Relation of strategies with competitive advantage.

Competitors add more features if needed to make the product more ideal to launch. If the features take more time than post-time is focused otherwise pre-time is suitable. In time product launch is ideal in the case of unique features are added in the product or the competitor is not launching its product at the same time. 
TABLE. I. STRATEGIES WITH THEIR MAIN PURPOSE

\begin{tabular}{|c|c|c|}
\hline Author \& Year & $\underline{\text { Strategy }}$ & Main purpose \\
\hline $\begin{array}{l}\text { John et al. } 2006 \text { [29], } \\
\text { Amir et al. } 2014 \text { [30], } \\
\text { Johnny } 2008 \text { [31], } \\
\text { Audhesh et al. 2012 [32], } \\
\text { Nadia \& Lassaad 2015[33], } \\
\text { Amir et al. } 2015 \text { [34], } \\
\text { David et al. } 2015 \text { [35], } \\
\text { Bulent et al. } 2007 \text { [36]. }\end{array}$ & Cost Leadership & About reducing the cost to the organization of delivering products or services. \\
\hline $\begin{array}{l}\text { John et al. 2006 [29], } \\
\text { Johnny } 2008 \text { [31], } \\
\text { Audhesh et al. 2012 [32], } \\
\text { Nadia \& Lassaad 2015 [33], } \\
\text { Devakumar \& Barani 2016 [37], } \\
\text { Jermias (2008) [38]. }\end{array}$ & Differentiation & Making your products or services unique from or more striking than those of your rivals. \\
\hline $\begin{array}{l}\text { Audhesh et al. } 2012 \text { [32], } \\
\text { Devakumar \& Barani 2016 [37]. }\end{array}$ & Focus & $\begin{array}{l}\text { Focus on a narrow fragment and within that fragment try to accomplish either cost advantage or } \\
\text { differentiation. }\end{array}$ \\
\hline $\begin{array}{l}\text { Gaurav \& Himanshu } 2016 \text { [39], } \\
\text { Wa'el } 2015 \text { [40]. }\end{array}$ & $\begin{array}{l}\text { Customer Relation } \\
\text { Management (CRM) }\end{array}$ & $\begin{array}{l}\text { Organizing a company's relations with existing and outlook customers for improving business } \\
\text { relationships and retaining customers }\end{array}$ \\
\hline John et al. $2006[29]$ & Customer Oriented & Concentrate on fulfilling a customer's needs except only increasing profit. \\
\hline $\begin{array}{l}\text { Devakumar \& Barani } \\
2016 \text { [37] }\end{array}$ & Market Penetration & $\begin{array}{l}\text { Practical for successfully using your product, when company enters a new market } \\
\text { Helpful to increase product demand and raise market outline. }\end{array}$ \\
\hline $\begin{array}{l}\text { John et al. } 2006[29] \\
\text { Bulent et al. } 2007[36]\end{array}$ & $\begin{array}{l}\text { Marketing and } \\
\text { Market Oriented }\end{array}$ & $\begin{array}{l}\text { Focus on how you increase sales by getting and keeping customers. Focus on the needs of the } \\
\text { market. }\end{array}$ \\
\hline Devakumar \& Barani 2016 [37] & Sale Service Support & Provide maintenance after delivering the services. \\
\hline John et al 2006 [39] & Staff Development & $\begin{array}{l}\text { The Staff Development Strategy is an information strategy with supporting process documents } \\
\text { for Staff Development topics }\end{array}$ \\
\hline Jeffrey \& Joohyung 2016 [31] & Family Owned & $\begin{array}{l}\text { In which two or more family members are concerned and the mainstream of rights or control lay } \\
\text { within a family. By using this strategy creativity, human resource efficiency, structural R\&D } \\
\text { factors, and cost in form of return and business growth may increases. }\end{array}$ \\
\hline Daniel 2016 [41] & Process Innovation & $\begin{array}{l}\text { Implementation of a new or considerably enhanced production or delivery processes (including } \\
\text { significant changes in techniques, equipment and/or software). }\end{array}$ \\
\hline $\begin{array}{l}\text { Daniel } 2016[41], \\
\text { Prajogo (2016) [42] }\end{array}$ & Product Innovation & $\begin{array}{l}\text { The introduction of a product or service that is innovative or considerably enhanced with respect } \\
\text { to its uniqueness or future uses. }\end{array}$ \\
\hline $\begin{array}{l}\text { Amir et al.2014 [30], } \\
\text { Amir et al. } 2015 \text { [34], } \\
\text { David et al. } 2015 \text { [35], } \\
\text { Bulent et al. } 2007 \text { [36], } \\
\text { Martie \& Denny } 2011 \text { [43]. }\end{array}$ & $\begin{array}{l}\text { Innovation } \\
\text { Differentiation }\end{array}$ & $\begin{array}{l}\text { Finding ways to optimize a precise set of differentiators that are most relevant to a specific set of } \\
\text { needs. }\end{array}$ \\
\hline $\begin{array}{l}\text { Amir et al. } 2014 \text { [30], } \\
\text { Amir et al } 2015 \text { [34]. }\end{array}$ & $\begin{array}{l}\text { Quality } \\
\text { Differentiation }\end{array}$ & Used to differentiate product in terms of quality \\
\hline $\begin{array}{l}\text { Amir et al. } 2014 \text { [30], } \\
\text { Amir et al } 2015 \text { [34]. }\end{array}$ & Service Differentiation & Used to differentiate product in terms of service \\
\hline $\begin{array}{l}\text { David et al. } 2015 \text { [35], } \\
\text { Bulent et al. } 2007 \text { [36], } \\
\text { Martie \& Denny } 2011 \text { [43]. }\end{array}$ & $\begin{array}{l}\text { Marketing } \\
\text { Differentiation }\end{array}$ & Used to differentiate product in terms of marketing \\
\hline
\end{tabular}

Fig. 3. shows some common factors that affect all three business strategies to gain competitive advantage. If all these three strategies would apply to any product development than the result will be an ideal product i.e. a unique product is developing at low cost with minimum time.

A unique product with innovation will impact positively on Differentiation but it will take the time to market, more maintenance will require, time is important here because uniqueness will take more time. A flexible process claims low cost while commercialization will increase the cost. A more suitable and concrete planning will aid time leadership along with time to market and market needs those also impact positively on it. Here, time to market has a positive impact on time leadership; therefore, we cannot neglect individuality of both. 


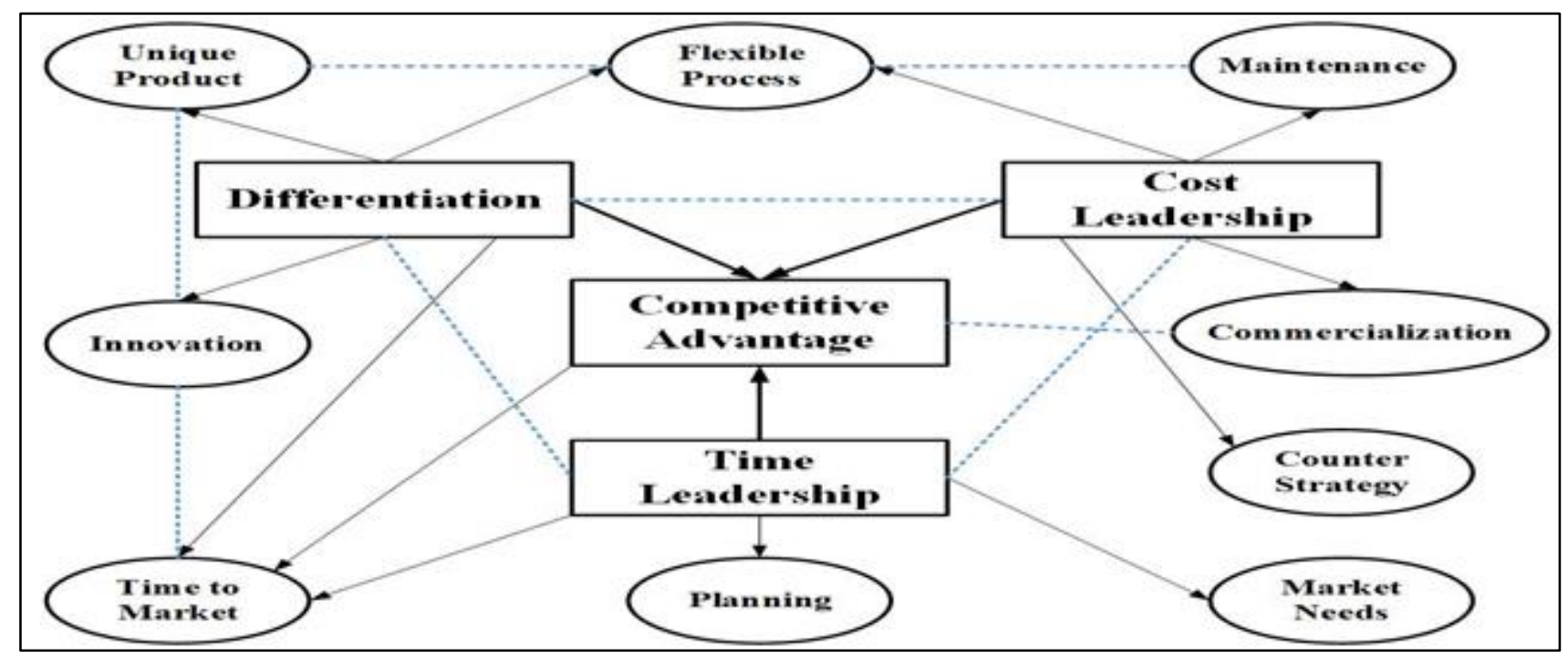

Fig. 3. Factors affecting strategies to gain competitive advantage.

\section{SimUlation RESUlts}

We only present simulation for limited scenarios here. Simulation results for more concrete and real scenarios will be investigated in the upcoming paper. According to the simulation results, right decision can be made by foreseeing the impact of the result in the future. To investigate the factors that have an impact on the competitive advantage with respect to time, an extensive literature was carried out. Most influencing factors are extracted and mapped with respect to time. Time-tomarket of own versus a competitor, resources, HR skills, Project management, features of the own product, competitors and maintenance were the factors that affect competitive advantage.

The Likert scale was initially used for all factors to get the idea of winning competitive advantage of company A against its competitors more simply. Time to market was calculated for 2 companies to start the simulation; i.e. company A and its competitor. Then the difference was analyzed. If the company A has more week's spare to launch than its competitor and number of features it has built are more and/or unique than company A has more chances of winning competitive advantage by launching the product in time. On contrast, if it has low features and then it has to apply a sub-strategy to launch the product in post-time after completing the features, adding some more features and improving the limitations found in the recently launched product by the competitor. It is obvious that all the competitors keep track of each other's products updated by different means. If the competitor has more chances of launching the product in-time as it has a more positive value of time to market as compared to company A than company A has no other option unless it launches at posttime. Here, to apply another strategy of increasing resources, by simulating time difference and features differences but it will increase the cost. Now, let us simulate the impact of competitive advantage dependency. After performing simulations, generated results are presented in graphs to represent the trends how different factors are influencing when a time-based strategy is introduced. Fig. 4. shows, when the time difference is greater than 0 and feature difference is equal or greater than 0 , then competitive advantage will be greater than zero and product could be launched. Competitive Advantage could be negative as well if the three differences go overall negative. In that case, Time based sub-strategies are applied as shown in Fig. 5.

\section{CONCLUSION AND FUTURE WORK}

We tried to highlight time-based competitive advantage with more focusing on time to complete and launch the product on pre-time, in time or post time to get the maximum advantage from the competitor. In the literature, time is used as a sub factor, however, intentions were to highlight its primary importance for example, in Information Technology time, cost and quality are most critical factors for a product to complete and majority of the software does not meet deadline and hence, their competitor take the advantage by launching the product at adequate time. They attract the market towards them. The simulation was performed to check the influence of different factors on time to get a competitive advantage. Small strategies were applied to get the competitive advantage with respect to the competitors. Simple scaling and raw data were used which will be replaced by the more concrete scale and empirical study in coming paper. We are claiming on this result that time-based competitive advantage needs primary importance as a strategy along with cost leadership and differentiation. In future work, we also intended to introduce time-based competitive advantage strategy in local as well as in global software development context (GSD). In GSD, time zone difference is the main reason for increasing problem in synchronous communication and not completing the project with-in time that leads to the failure of the projects or causing a delay in the launching of the product. By introducing time-based strategy in global context, we may gain a competitive advantage in round the clock development as compared to our competitors. 


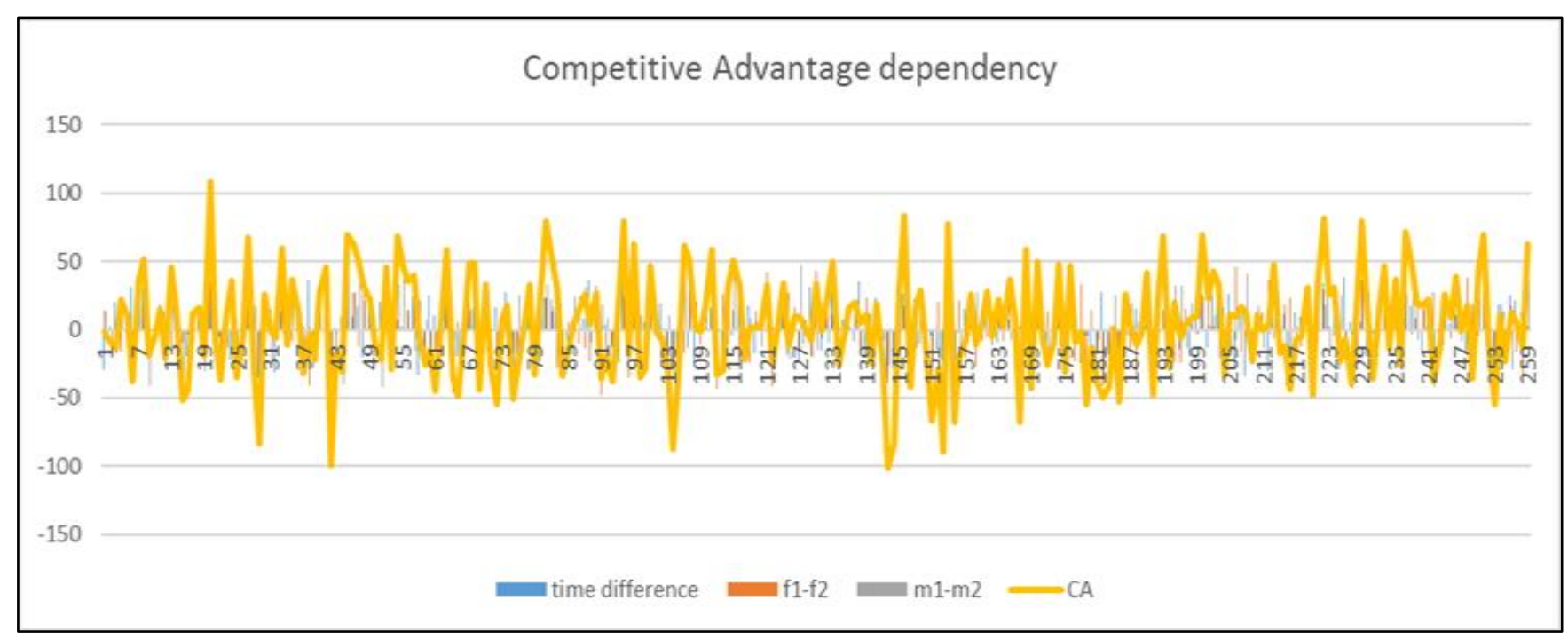

Fig. 4. Dependency of competitive advantage.

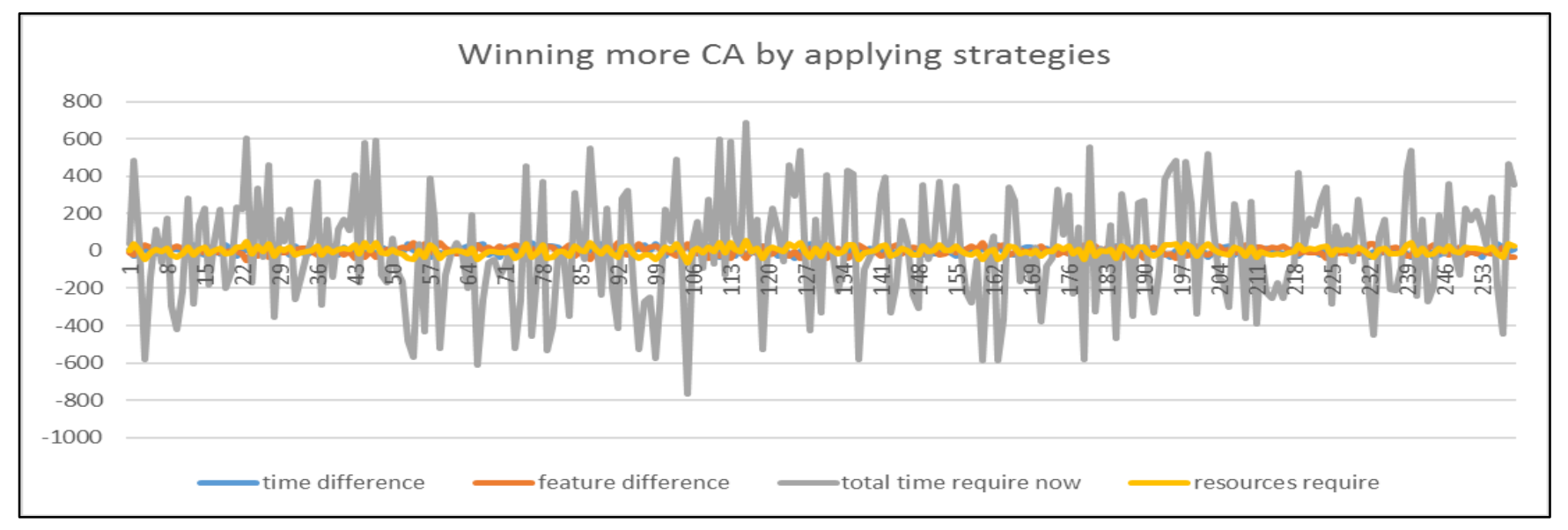

Fig. 5. Sub-strategies for winning competitive advantage.

\section{REFERENCES}

[1] Chandler et al.,"Strategy and Structures: Chapters in the History of the Industrial Enterprise," MIT Press, Vol. 120, 1990.

[2] M.E. Porter,"What is Strategy?," Harvard Business Review, pp. 61-78, 1996.

[3] M.E.Porter, "Competitive Advantage: Creating and Sustaining Superior Performance," New York, The Free Press, 1985.

[4] A.Brandenburger and B. J. Nalebuff, Co-opetition, New York: Doubleday, 1996.

[5] J.B.Barney, "Gaining and Sustaining Competitive Advantage," U.S.A., Addison-Wesley, 1997.

[6] Wang et al.,"Types of Competitive Advantage and Analysis," International Journal of Business and Management, vol. 6, no. 5, pp.100104, 2011.

[7] A.C.Cooper et al., "Strategies of high performing new and small firms: A reexamination of the niche concept." Journal of Business Venturing, vol. 1, no. 3, pp.247-260, 1986.

[8] E.Mosakowski, "A resource-based perspective on the dynamic strategyperformance relationship: An empirical examination of the focus and differentiation strategies," Journal of Management, vol. 19, no. 4, pp. 819-839, 1993.

[9] D.Smallbone et al., "The Characteristics and Strategies of Fast Growth
SMEs", International Journal of Entrepreneurial Behavior \& Research, vol. 1, no.3, pp. 44-62, 1995.

[10] J. Barney, "Firm Resources and Sustained Competitive Advantage," Journal of management, vol. 17, no.1, pp. 99-120, 1991.

[11] N.Bontis, "Intellectual capital: an exploratory study that develops measures and models," Manage.Decision, vol. 36, no. 2, pp. 63-76, 1998.

[12] M.E.Porter, "Competitive Advantage". Ch. 1, pp 11-15, New York, The Free Press, 1985.

[13] R.Panwar et al., " The effect of small firms' competitive strategies on their community and environmental engagement," Journal of Cleaner Production, vol. 129, pp. 578-585, 2016.

[14] R.M.Beal and Y.Ardekani, "Performance implications of aligning CEO functional experiences with competitive strategies," Journal of Management, vol. 26, no. 4, pp. 733-762, 2000.

[15] P.S.Gopalakrishna, "Revisiting the pure versus hybrid dilemma: Porter's generic strategies in a developing economy," Journal of Global Marketing, vol.15, pp. 61-79, 2001.

[16] K.W.M.Tyson, "Competition in the 21st Century. New York, St Lucie Press, pp. 64, 1997

[17] M.A.Maidique and P.Patch, "Corporate strategy and technological policy”. Management of innovation, pp. 273-285, 1982.

[18] G.Stalk and T.Hout, Competing against time. New York, Free press, 1990. 
[19] D.Avison et al., "Using and validating the strategic alignment model," The Journal of Strategic Information Systems., vol. 13, no. 3, pp. 223246, 2004.

[20] S.J.Bleistein et al., "Validating strategic alignment of organizational IT requirements using goal modeling and problem diagrams," Journal of Systems and Software, vol. 79, pp. 362-378, 2006.

[21] Society For Information Management, IT Management Concerns Survey, What keeps CIO awakeatnight? , 2006.

[22] Y.E.Chan et al., "Business strategic orientation, information systems strategic orientation, and strategic alignment," Information systems research, vol. 8, no. 2, pp. 125-150, 1997.

[23] J.Coughlan et al., "Understanding the business-IT relationship", International Journal of Information Management, vol. 25, no.4, pp. 303-319, 2005.

[24] J.DeLeede et al., "Innovation, improvement and operations: an exploration of the management of alignment," International Journal of Technology Management, vol. 23, no. 4, pp. 353-368, 2002.

[25] V.A.Hooper et al., "The impact of IS-marketing alignment on marketing performance and business performance," The DATA Base for Advances in Information Systems, ACM SIGMIS Database, vol. 41, pp. $36-55,2010$.

[26] G.S.Kearns and A.L.Lederer, "Are source based view of strategic IT alignment: how knowledge sharing creates competitive advantage," Decision sciences, vol. 34, no. 1, pp. 1-29, 2003.

[27] C.Pereira, P.Sousa, "Getting into the misalignment between Business and Infor-mation Systems": 10th European Conference on Information Technology Evaluation, Madrid, Spain. 2003.

[28] Chaos, The Standish Group Report. 2014.

[29] J. a Parnell, N. O'Regan, and A. Ghobadian, "Measuring Performance in Competitive Strategy Research," International. Journal of Management and. Decision Making., vol. 7, no. 4, pp. 408-417, 2006.

[30] A Samarrokhi, K. Jenab, V. C. Arumugam, and P. D. Weinsier, "A new model for achieving sustainable competitive advantage through operations strategies in manufacturing companies," International Journal of Logistics Systems and Management, vol. 19, no. 1, pp. 115-130, 2014.

[31] J. M. Campbell and J. Park, "Internal and external resources of competitive advantage for small business success: validation across family ownership," International Journal of Entrepreneurship and Small Business, vol. 27, no. 4, pp. 505-524, 2016.

[32] A. K. Paswan, F. Guzm??n, and C. Blankson, "Business to business governance structure and marketing strategy," International Journal of
Business and Management, vol. 41, no. 6, pp. 908-918, 2012.

[33] N. Ben Romdhane Ladib and L. Lakhal, "Alignment between business model and business strategy and contribution to the performance: Empirical evidence from ICT Tunisian venture," The Journal of High Technology Management Research, vol. 26, no. 2, pp. 168-176, 2015.

[34] A. Samarrokhi, K. Jenab, V. C. Arumugam, and P. D. Weinsier, "Analysis of the effects of operations strategies on sustainable competitive advantage in manufacturing systems," International Journal of Industrial and Systems Engineering, vol. 19, no. 1, p. 34, 2015.

[35] M.S. David, C. Devece, C.L. Albert. "How information systems strategy moderates the relationship between business strategy and performance." Journal of Business Research vol. 68, no. 7, pp. 15921594, 2015.

[36] M. Bulent, S. Auh, and E. Shih. "Transformational leadership and market orientation: Implications for the implementation of competitive strategies and business unit performance." Journal of Business Research, vol. 60, no. 4, pp. 314-321, 2007.

[37] G. Devakumar and G. Barani, "Marketing strategies for competitive advantage: structural equation modelling approach on agricultural sector industry in South India," International Journal of Business Excellence, vol. 9, no. 2, pp. 225-239, 2016.

[38] J. Jermias, "The relative influence of competitive intensity and business strategy on the relationship between financial leverage and performance," The British Accounting Review., vol. 40, no. 1, pp. 7186, 2008.

[39] G. Gupta and H. Aggarwal,“ Analysing customer responses to migrate strategies in making retailing and CRM effective," International Journal of Indian Culture and Business Management vol. 12, no. 1, pp. 92-127, 2016.

[40] W. Hadi, "The Relationship between CRM Strategies Stage on Competitive Advantage: An Analytical Perspective," International Journal of Business and Management, vol. 10, no. 8, pp. 245-252, 2015.

[41] P. I. Daneial "The strategic fit between innovation strategies and business environment in delivering business performance." International Journal of Production Economics, vol. 171, pp. 241-249, 2016.

[42] D. I. Prajogo, "The strategic fit between innovation strategies and business environment in delivering business performance," International Journal of Production Economics, vol. 171, pp. 241-249, 2014.

[43] M. L. Verreynne and D. Meyer, "Differentiation strategies in mature small firms - the impact of uncertain environments," International Journal of Entrepreneurship and Small Business, vol. 12, no. 3, p. 327, 2011. 